\title{
PROPERTY CHARACTERIZATION OF Chusquea culeou, A BAMBOO GROWING IN CHILE
}

\author{
Hernán Poblete $^{1}$; Héctor Cuevas ${ }^{1}$; Juan E. Diaz-Vaz
}

\begin{abstract}
Property characterization of Chusquea culeou Desv. (colihue), a bamboo growing in Chile, was conducted. Physical, chemical and mechanical properties were determined as a function of plant diameter, position in culm length and nodal or internodal sections.

The results show that fibre length increased from the base to the top of the culms. Differences in the fibre length between nodes and internodes were observed. In the internodes higher moisture content, lower specific gravity and lower extractive content were also found. Extracts and ash content in the samples tested were higher than those determined for commercial Chilean woods. Hemicellulose, cellulose, and lignin proportion indicate that the colihue could be used as raw material for pulp and paper production.
\end{abstract}

The measured mechanical properties (bending strength, compression, hardness, shear strength) are higher than those of poplar wood but lower than radiata pine growing in Chile.

Keywords: Chusquea culeou, bamboo, mechanical properties, chemical properties.

\section{INTRODUCTION}

Colihue (Chusquea culeou Desv.) is one of the eleven bamboo species of the Chusquea genus growing in Chile. It has a high growing rate and biomass production (Veblen et al. 1979). Campos et al. (2003) did an estimate about the forest land of 180.000 ha in which Chusquea culeou was growing with a productivity of $10 \mathrm{t} / \mathrm{ha} /$ year or $12 \mathrm{~m}^{3} / \mathrm{ha} /$ year. However, due to the lack of knowledge about technological properties and characteristics of this material, colihue is at the present not widely utilised in industry in Chile (Campos et al. 2003).

Based on the work of Veblen et al. (1979) and Rijo et al. (1987), this study aims to investigate the properties and variation of colihue wood. The physical and mechanical properties, anatomical structure, fibre length and chemical composition will be measured in this work.

\section{MATERIALS AND METHODS}

Samples of colihue culms were prepared from selected culms that had a strait form without visual insect attack. The culms were classified into two categories based on diameter $(>3 \mathrm{~cm}$ and thin $<3 \mathrm{~cm})$ and each category consisted of 200 culms. Test samples, $5 \mathrm{~cm}$ long were cut from the top, middle and base of each culm and analysed. The test samples included nodal and internodal sections.

\footnotetext{
${ }^{1}$ Inst. Tecnología de Productos Forestales. Universidad Austral de Chile. Valdivia, Chile

Correspondig author: hernanpoblete@uach.cl

Received: 14.11.2008 Accepted: 13.05.2009
} 


\section{Physical and anatomical properties}

Moisture content DIN 1992a (DIN 52 183: Bestimmung des Feuchtigkeitsgehaltes), specific gravity DIN 1992b (DIN 52 182: Bestimmung der Rohdichte), fibre length and anatomical observations were conducted. These properties were determined for each diameter category at different positions in the culm height and with nodes or internodes.

\section{Chemical composition}

Samples for the chemical analysis were randomly selected from colihue culms considering nodes and internodes. Each sample was processed in a Willey grader. The obtained dust was classified and the chemical composition was analysed according to TAPPI standards. Extractives in cold and boiling water, $1 \% \mathrm{NaOH}$, ethanol and ethanol toluene according to TAPPI 2000a (TAPPI T 204-cm-97) were determined. Determinations of holocellulose according to Poljak (Navarro 1970), cellulose according to Kurschner and Hoffer (Navarro 1970) and lignin TAPPI 2000b (TAPPI T 222 om-98) were also conducted.

\section{Mechanical properties}

For the mechanical properties, test samples including nodes and internodes were prepared. After preparation the test samples were stored in a climatic chamber at $20 \pm 2^{\circ} \mathrm{C}$ with $65 \pm 5 \%$ relative air humidity until constant weight was achieved. Shear strength according to ASTM 1995 (ASTM D-5751), MOR and MOE DIN 1992c (DIN 52 186: Biegeversuch.), compression parallel to fibres DIN 1992d (DIN 52 185: Bestimmung der Druckfestigkeit parallel zur Faser), and hardness (Janka) were tested.

To cut the test samples of colihue, it was necessary to eliminate the outer part of the culm. This is important because the "skin" of the culm has a higher density. As an example, in Figure 1 shows samples for shear strength test one set with and the other without nodes.

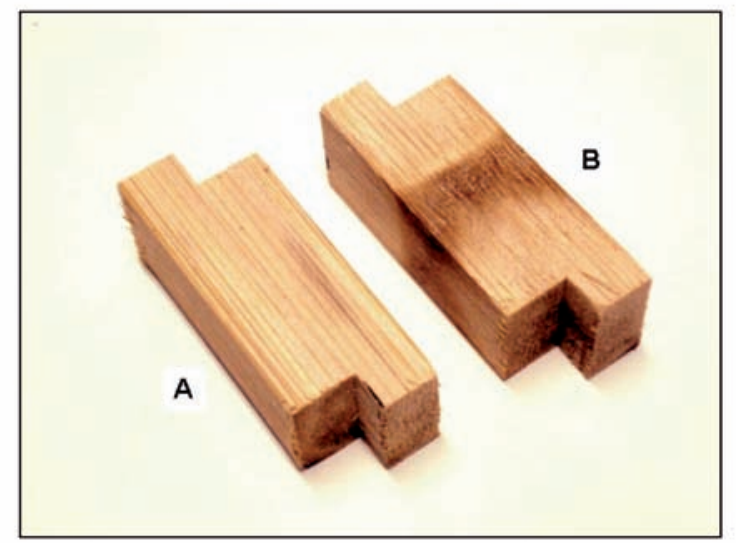

Figure 1. Shear test samples. A: without node, B: node at the centre.

\section{RESULTS}

\section{ANATOMICAL STRUCTURE AND PHYSICAL PROPERTIES}

The bamboo culms are usually formed with about $50 \%$ of parenchyma cells, $40 \%$ fibres and $10 \%$ to vessels and sieve tubes. The proportion of cell types varies within a single culm, across the length and width. In Figure 2 examples of the anatomical structure of Chusquea culeou for nodes and internodes in transversal preparations are shown. 


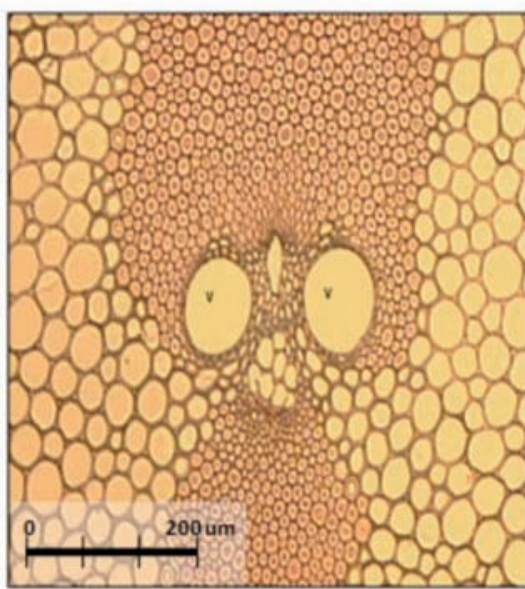

a. Node section (Scale: 200 um)

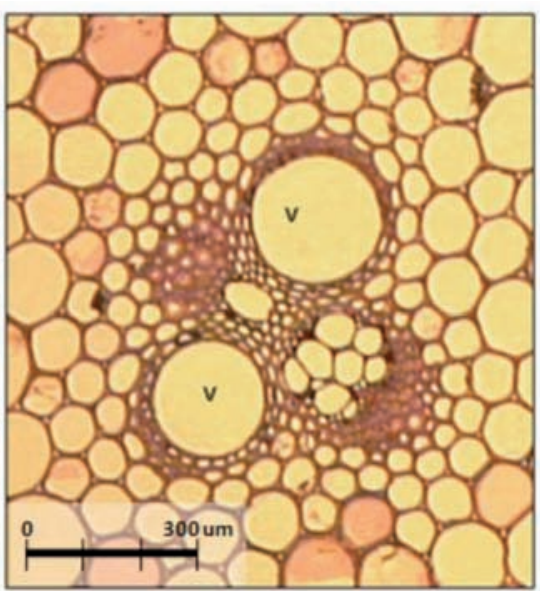

b. Inter nodal section (Scale: 300 um)

Figure 2. Transversal sections of colihue.

As observed in Figure 2 both for nodes and internodes, vascular bundles with one phloem field and two metaxylem vessels (labelled as V) are always present. The vascular bundles are surrounded by fibres, and the whole insert in parenchyma tissue. The phloem field looks like a cluster arranged and located within the two vessels.

The parenchyma tissue surrounding vessels and phloem has thin cell walls and round section. This tissue contain relatively small intercellular spaces which may not be visible in some cases.

The most important difference between nodes and internodes is the fibre wall thickness. In the nodes sections fibres have thicker cell walls and the high proportion of fibres in every vascular bundle and the higher amount of vascular bundles, are probably responsible for the higher specific gravity of this part of the culms

\section{Fibre length}

Figure 3 shows the average fibre length of both node and internodes samples for three positions (base, middle culm height and top). The error bars show the maximum and minimum values for each category. 


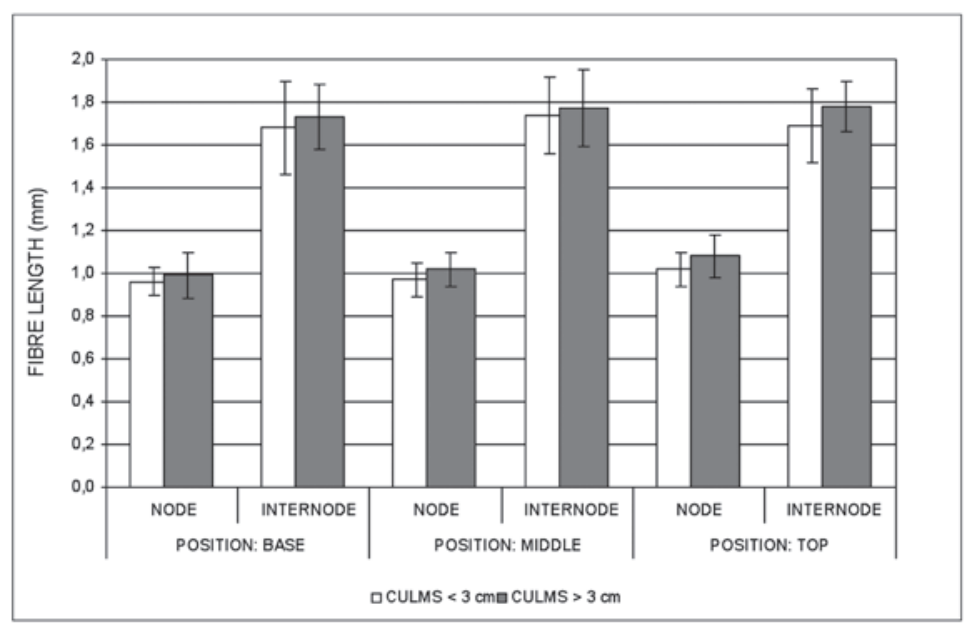

Figure 3. Average fibre length of colihue with two diameter classes $(<3 \mathrm{~cm},>3 \mathrm{~cm})$, three positions in culm height and in nodes or internodes sections.

According to results presented in Figure 3, culms nodes with less than $3 \mathrm{~cm}$ in diameter presented fibre lengths that fluctuate between $0,96 \mathrm{~mm}$ and $1,02 \mathrm{~mm}$. In the internodes the fibre length varied from a minimum value of $1,68 \mathrm{~mm}$ and a maximum of $1,74 \mathrm{~mm}$. The position in the culm height did not have a significant effect on fibre length.

Culms with diameters bigger than $3 \mathrm{~cm}$ had average fibre lengths between 1,00 $\mathrm{mm}$ and 1,08 $\mathrm{mm}$ in nodal sections while the intermodal material had an average fibre length between $1,73 \mathrm{~mm}$ and 1,78 $\mathrm{mm}$.

\section{Specific gravity}

Figure 4 presents the average specific gravity of both node and internodes samples for three positions (base, middle culm height and top). The error bars show the maximum and minimum values for each category.

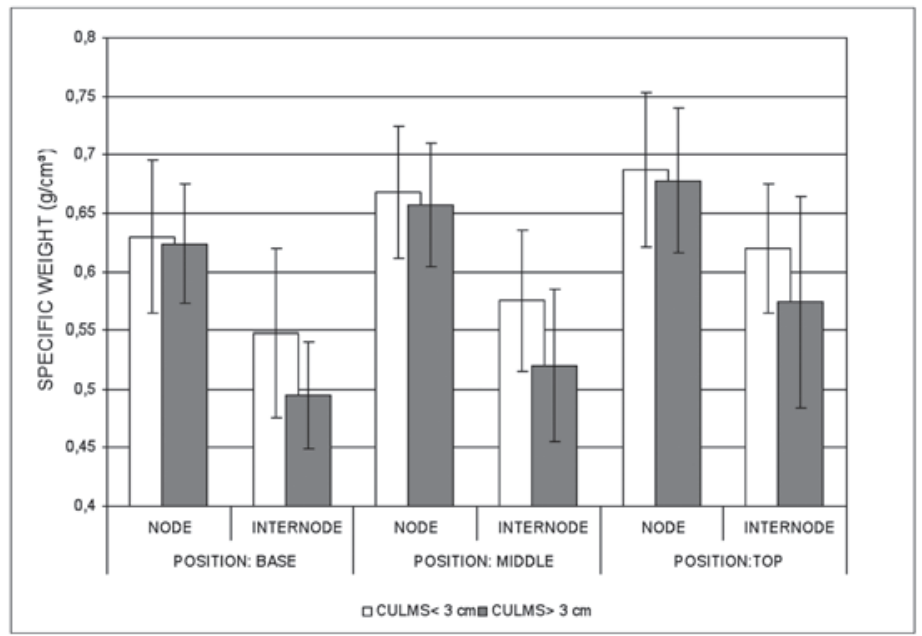

Figure 4. Specific gravity of colihue, two diameter classes $(<3 \mathrm{~cm},>3 \mathrm{~cm})$, three positions in culm height for nodes or internodes sections. 
The specific gravity of the node sections of the material from smaller diameter culms (less than $3 \mathrm{~cm}$ ) showed a variation between $0,631 \mathrm{~g} / \mathrm{cm}^{3}$ and $0,685 \mathrm{~g} / \mathrm{cm}^{3}$. The internodal sections had lower values, with a minimum value of $0,549 \mathrm{~g} / \mathrm{cm}^{3}$ and a maximum value of $0,616 \mathrm{~g} / \mathrm{cm}^{3}$.

The specific gravity of the culms with diameters bigger than $3 \mathrm{~cm}$ was lower than the measured values in small culms in the internodal sections. The nodal sections of the two diameter classes showed no significant differences in their specific gravity.

When the height position in culm was considered, an increase in the specific gravity from base to top was detected.

\section{Moisture content}

In Figure 5 the average, maximum and minimum moisture content of fresh harvested culms are presented. The determinations considered diameter classes, nodal and internodal sections, and three positions in the culm height (base, middle and top).

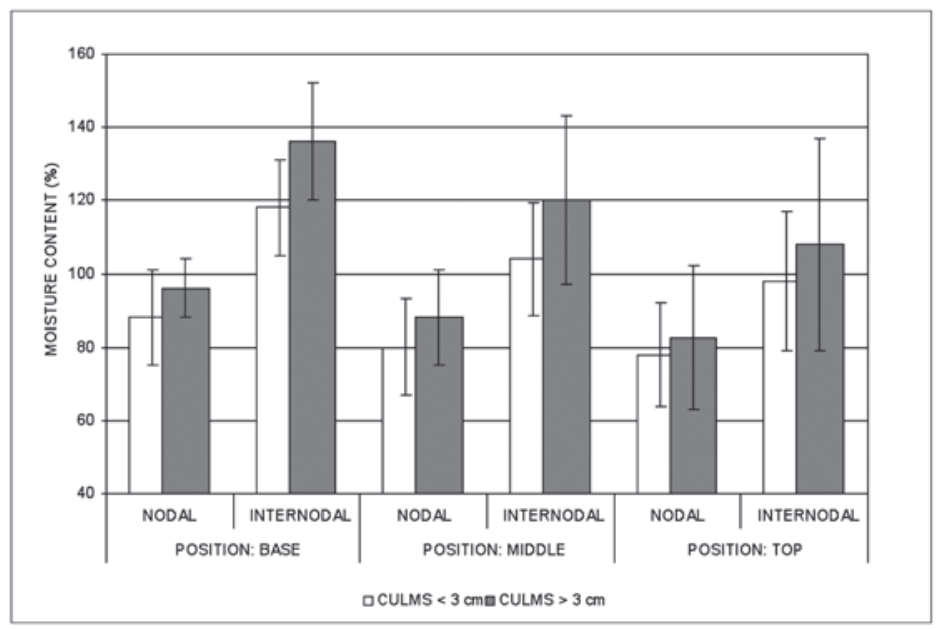

Figure 5. Moisture content of colihue, considering two diameter classes $(<3 \mathrm{~cm},>3 \mathrm{~cm})$, three positions in culm height for nodes or internodes sections.

The moisture content was always higher in the internodal sections than in the nodal sections. Culms with bigger diameter $(>3 \mathrm{~cm})$ showed higher moisture contents than the smaller diameter culms $(<$ $3 \mathrm{~cm})$. Both diameter classes showed a slight trend to decrease in the moisture content from the base to the top of the culm.

\section{Chemical Composition}

In Table 1 the average content of chemical components, in nodal and intermodal sections are shown. The internodal material had a higher amount of extractives. The high content of extractable compounds (average 17,3\%), mostly acidic in nature, is reflected in the $\mathrm{pH}$ value. This characteristic could have some consequences during industrial utilization of colihue (Roffael and Stegmann 1983).

Due to the high amount of cellulose, colihue appears to be an appropriate raw material for the pulp and paper production. 
Table 1. Chemical composition of nodal and intermodal sections of colihue

\begin{tabular}{|c|c|c|}
\hline Extractives: & $\begin{array}{c}\text { NODAL } \\
(\%)\end{array}$ & $\begin{array}{c}\text { INTERNODAL } \\
(\%)\end{array}$ \\
\hline Cold water & 12,6 & 13,1 \\
\hline Boiling water & 13,2 & 14,3 \\
\hline $\mathrm{NaOH}(1 \%)$ & 32,0 & 33,5 \\
\hline Ethanol & 15,5 & 16,1 \\
\hline Ethanol-toluene & 14,6 & 14,9 \\
\hline Total extractable compounds & 16,8 & 17,8 \\
\hline Holocellulose & 73,1 & 71,9 \\
\hline Cellulose & 51,4 & 51,5 \\
\hline Lignin & 22,3 & 23,0 \\
\hline Ashes & 1,2 & 1,3 \\
\hline $\mathrm{pH}$ - cold water extractive & 3,5 & 3,7 \\
\hline $\mathrm{pH}$ - boiling water extractive & 4,5 & 4,6 \\
\hline
\end{tabular}

The ash content from this bamboo is almost four times higher than the reported values for other wood species growing in Chile. This high content of minerals in the ash could cause a loss of sharpness of cutting tools during industrial processing.

\section{MECHANICAL PROPERTIES}

\section{Shear strength}

Average values for shear strength of the test samples with and without nodes are presented in Table 2.

The results show that there is no significant difference in the shear strength between nodes and internodes. The obtained shear strength is higher than values reported by Perez (1983) for Populus sp. and similar to the values obtained with Pinus radiata, 6,0 and $9,8 \mathrm{~N} / \mathrm{mm}^{2}$ respectively.

Table 2. Shear strength

\begin{tabular}{|l|c|c|}
\hline \multicolumn{1}{|c|}{ Parameter } & $\begin{array}{c}\text { NODAL } \\
\left(\mathrm{N} / \mathrm{mm}^{2}\right)\end{array}$ & $\begin{array}{c}\text { INTERNODAL } \\
\left(\mathrm{N} / \mathrm{mm}^{2}\right)\end{array}$ \\
\hline Average & 9,05 & 9,09 \\
Standard Dev. & 1,72 & 1,74 \\
Variation Coefficient & 1,86 & 1,88 \\
Minimum & 5,63 & 6,33 \\
Maximum & 13,72 & 13,26 \\
\hline
\end{tabular}

\section{Bending strength (MOR and MOE)}

In Table 3 bending strength (MOR) and stiffness (MOE) values for nodes and internodes samples are presented. 
Table 3. Bending strength, MOR and MOE.

\begin{tabular}{|l|c|c|c|c|c|c|}
\hline \multirow{1}{*}{ Parameter } & \multicolumn{3}{|c|}{ NODAL } & \multicolumn{3}{c|}{ INTERNODAL } \\
\cline { 2 - 7 } & $\begin{array}{c}\text { Fibre stress at } \\
\text { proportional } \\
\text { limit }\left(\sigma_{\mathrm{PL}}\right) \\
\left(\mathrm{N} / \mathrm{mm}^{2}\right)\end{array}$ & $\begin{array}{c}\text { MOR } \\
\left(\mathrm{N} / \mathrm{mm}^{2}\right)\end{array}$ & $\begin{array}{c}\text { MOE } \\
\left(\mathrm{N} / \mathrm{mm}^{2}\right)\end{array}$ & $\begin{array}{c}\text { Fibre stress at } \\
\text { proportional } \\
\text { limit }\left(\sigma_{\mathrm{PL}}\right) \\
\left(\mathrm{N} / \mathrm{mm}^{2}\right)\end{array}$ & $\begin{array}{c}\text { MOR } \\
\left(\mathrm{N} / \mathrm{mm}^{2}\right)\end{array}$ & $\begin{array}{c}\mathrm{MOE} \\
\left(\mathrm{N} / \mathrm{mm}^{2}\right)\end{array}$ \\
\hline Average & 34,9 & 59,9 & 7.326 & 30,8 & 61,9 & 6.638 \\
Standard Dev. & 9,9 & 15,4 & 1.974 & 10,2 & 16,2 & 1.692 \\
Variation Coef. & 2,8 & 2,5 & 2,64 & 17,1 & 2,6 & 2,58 \\
Minimum & 19,3 & 35,9 & 4.468 & 17,1 & 37,2 & 3.765 \\
Maximum & 56,3 & 93,2 & 11.419 & 60,7 & 96,3 & 10.426 \\
\hline
\end{tabular}

From the results, it is found that the MOR value was lower in the node sample whereas the MOE value was lower in the internodes samples. The average tension at the proportional limit was higher in the nodes samples.

According to MOE results, the samples with nodes were more rigid than those prepared only with internodal material. Observations on fracture characteristics after testing (failure type) showed significant differences between nodes and internodes. The fractures in all test samples with nodes have a well defined vertical plane. However, in the samples without nodes the material breaks in an irregular way, in the tension zone (Figure 6).

The average MOR values of colihue are slightly higher than those reported for poplar (a low density hardwood) and are lower than radiata pine growing in Chile (Perez 1983). According to the MOE results and comparing with other wooden species, colihue is stiffer than poplar wood.

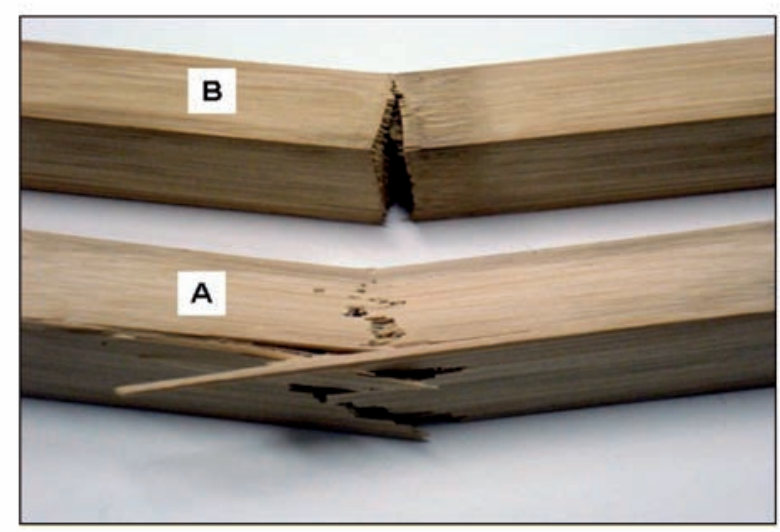

Figure 6. Failure types in bending strength.

A: Test sample without node; B: Test sample with node in the centre.

\section{Parallel compression}

In Table 4 average and statistical values for parallel compression strength of test samples with and without nodes are presented. 
Table 4. Parallel compression

\begin{tabular}{|l|c|c|}
\hline \multicolumn{1}{|c|}{ Parameter } & $\begin{array}{c}\text { NODAL } \\
\left(\mathrm{N} / \mathrm{mm}^{2}\right)\end{array}$ & $\begin{array}{c}\text { INTERNODAL } \\
\left(\mathrm{N} / \mathrm{mm}^{2}\right)\end{array}$ \\
\hline Average & 26,2 & 26,2 \\
Standard Dev. & 4,7 & 5,5 \\
Variation Coefficient & 1,8 & 2,1 \\
Minimum & 16,7 & 17,5 \\
Maximum & 34,8 & 37,7 \\
\hline
\end{tabular}

According to the measured values, no significant differences in the parallel compression strength between nodal and internodal samples were observed. The obtained compression strength values are lower than the reported values for wooden species growing in Chile. Perez (1983) reported 29,6 N/mm² for Populus sp. and 39,2 N/mm² for Pinus radiata

\section{Janka hardness}

In Table 5 hardness values for colihue test samples with and without nodes are presented. It's important to consider that in preparing samples, the outer part of the colihue culm, which has a much higher density than other parts, was eliminated.

Table 5. Janka Hardness

\begin{tabular}{|l|c|c|}
\hline \multicolumn{1}{|c|}{ Parameter } & $\begin{array}{c}\text { NODAL } \\
(\mathrm{N})\end{array}$ & $\begin{array}{c}\text { INTERNODAL } \\
(\mathrm{N})\end{array}$ \\
\hline Average & 3396 & 2156 \\
Standard Dev. & 556 & 719 \\
Variation Coefficient & 160 & 327 \\
Minimum & 1961 & 1167 \\
Maximum & 4472 & 3727 \\
\hline
\end{tabular}

Compared with most of wood species, the average hardness values of colihue are low and its use is restricted to production of decorative elements, handicrafts or some parts of furniture. However, according to values reported by Perez (1983), the average hardness of colihue is higher than poplar (1373 N) and similar to radiata pine $(2600 \mathrm{~N})$. The reported values for the node structure are about $57 \%$ higher than the obtained from the internodal sections.

\section{CONCLUSIONS}

The physical, chemical and properties were measured on Chusquea culeou culms, classified in two diameter classes (bigger or thinner than $3 \mathrm{~cm}$ ). The results on the fibre length showed that there are significant differences between nodal and intermodal sections. The analysis of fibre length according to the position in culm height (base, middle or top) did not reveal significant variations. 
Specific gravity is higher in the nodes sections than in the internodal material. This property increases with the culm height from the base to the top. This relationship was similar for both diameter classes.

Independent from the culm diameter, moisture content was always higher in the intermodal sections than in the nodal sections. A weak tendency of moisture content decreasing with the culm height was determined.

The measured extractive content was determined using cold and boiling water, $1 \% \mathrm{NaOH}$, ethanol and ethanol toluene respectively, and the results show that its values is lower in nodal sections than in the internodes. Ash content was also measured but no significant differences were found between nodes and internodes. Ash content of colihue is about four times higher than the average values obtained in wood.

The proportions of the principal compounds of colihue (cellulose, lignin and holocellulose) are similar to those determined in hardwoods growing in Chile. The lignin content is slightly higher in the internodal material.

The results of measured MOR and MOE in bending, shear strength and Janka hardness for culms are towards the low boundary in commercial wood species, similar to poplar, a wood with the lowest mechanical properties in Chile. In general, the measured mechanical properties of colihue indicate that it could be used as raw material for decorative panels, handicrafts and some furniture parts.

Considering the specific gravity, the fibre length and chemical constitution, studies about the use of colihue as raw material for particle boards, fibreboards and paper production should be investigated in future studies.

\section{REFERENCES}

ASTM. 1995. Standard specifications for adhesives used for laminate joints in non-structural lumber products. ASTM D-5751. American Society for Testing and Materials.

Campos, J.; Peñaloza, R.; Kahler, C.; Poblete, H.; Cabrera, J. 2003. Bambú en Chile. Corporación de Investigación Tecnológica de Chile, Universidad Austral de Chile, FONDEF. 144p.

DIN. 1992a. Deutsches Institut für Normung. Taschenbuchh 31, Normen über Holz. Prüfung von Holz; Bestimmung des Feuchtigkeitsgehaltes. DIN 52 183. Berlin: Beuth Verlag.

DIN. 1992b. Deutsches Institut für Normung. Taschenbuch 31, Normen über Holz. Prüfung von Holz; Bestimmung der Rohdichte. DIN 52 182. Berlin: Beuth Verlag.

DIN 1992c. Deutsches Institut für Normung. Taschenbuch 31, Normen über Holz. Prüfung von Holz; Biegeversuch. DIN 52 186. Berlin: Beuth Verlag.

DIN 1992d. Deutsches Institut für Normung. Taschenbuch 31, Normen über Holz. Prüfung von Holz; Bestimmung der Druckfestigkeit parallel zur Faser. DIN 52 185. Berlin: Beuth Verlag.

Navarro S, J. 1970. Temas de la fabricación de papel. Editorial Marfil S.A. España: 59-64.

Perez, V. 1983. Manual de propiedades físicas y mecánicas de maderas chilenas. Chile. CONAFFAO. Documento de trabajo $\mathrm{N}^{\circ} 47$. 
Rijo, C.; Poblete, H.; Diaz-Vaz, J.E.; Torres, M.; Fernandez, A. 1987. Estudio de algunas características anatómicas, físicas y químicas de Chusquea culeou (Colihue). Bosque 8(1): 59-61.

Roffael, E., Stegmann, G. 1983. Zur Bedeutung der Holz- Extraktstoffe in chemisch- technologischer Hinsicht. Adhäsion 7-8: 7-19.

TAPPI. 2000a. Solvent Extractives of Wood and Pulp. T $204 \mathrm{~cm}$ 97. TAPPI Test Methods 20002001. Technical Association of the Pulp and Paper Industry. Atlanta, USA.

TAPPI. 2000b. Acid-Insoluble Lignin in Wood and Pulp. T 222 om 98. TAPPI Test Methods 20002001. Technical Association of the Pulp and Paper Industry. Atlanta, USA.

Veblen, T.; Schlegel, F.; Escobar, B. 1979. Biomasa y producción primaria de Chusquea culeou Desv. y Chusquea tenuiflora Phil. en el sur de Chile. Bosque 3(1):47-56. 